\title{
A retrospective study of cases diagnosed with cystic fibrosis at a single care center in Syria
}

\author{
Raghad Al-Baba* and Almoutassem Billah Zetoune
}

\begin{abstract}
Background: Although there is relatively much information about the status of cystic fibrosis disease in different countries of the world, limited data are available on this disease among Syrian children. Therefore, we did a retrospective study that included 173 children diagnosed with cystic fibrosis according to the diagnostic criteria. This study was conducted to determine the diagnostic, clinical, and genetic characteristics of patients with cystic fibrosis in Syria and to assess the relationship between the genotype and the phenotype of disease in these patients.

Results: As a result of the early classical manifestations, CF diagnosis was established in the present study by the age of 1 year in $78.6 \%$; the mortality rate was $23.1 \%$ (82.5\% of them were in the first year of life). The prevalence of respiratory and gastrointestinal symptoms was $81.5 \%$ and $78.6 \%$, respectively with an average age of 7.8 and 3.4 months. Consanguinity was reported in $75.7 \%$ of the families. The most common pathogenic variant in the sample was F508del (36\%) followed by W1282X (17\%). There was a statistical correlation between incidence of steatorrhea and the presence of class I pathogenic variants. A relationship between the mortality rate and the presence of class II pathogenic variants (pathogenic deletion variants) was also observed. There was no statistical relationship between other clinical manifestation and pathogenic variant classes. However, the incidence of most CF-related conditions was a little higher in the presence of classes I, II, and III pathogenic variants compared to their incidence in the presence of classes IV and $V$ pathogenic variants.

Conclusions: The number of cases diagnosed with cystic fibrosis in Syria is less than the number of real cases, and there is a need to perform CFTR gene sequencing on large sample sizes, to determine all CFTR pathogenic variants that could exist in Syrian patients and to make a better evaluation of the relationship between genotype and phenotype of the disease.
\end{abstract}

Keywords: Cystic fibrosis, CFTR, Syria

\section{Background}

Cystic fibrosis (CF) is one of the most common recessive genetic diseases among populations of Caucasian which is associated with an early death. CF is caused by pathogenic variants in the cystic fibrosis transmembrane conductance regulator (CFTR) gene which is located on the long arm of chromosome 7(q31.27). The CFTR protein

* Correspondence: raghadpha93@gmail.com

Department of Biochemistry and Microbiology, Faculty of Pharmacy, Damascus University, Damascus, Syria

(0) The Author(s). 2021 Open Access This article is licensed under a Creative Commons Attribution 4.0 International License, which permits use, sharing, adaptation, distribution and reproduction in any medium or format, as long as you give appropriate credit to the original author(s) and the source, provide a link to the Creative Commons licence, and indicate if changes were made. The images or other third party material in this article are included in the article's Creative Commons licence, unless indicated otherwise in a credit line to the material. If material is not included in the article's Creative Commons licence and your intended use is not permitted by statutory regulation or exceeds the permitted use, you will need to obtain permission directly from the copyright holder. To view a copy of this licence, visit http://creativecommons.org/licenses/by/4.0/. 
genetic factors, such as the genetic modifications that could be found on other genes [1].

Since 1989, over 2000 different pathogenic variants have been described. The distribution of CFTR pathogenic variants varies according to different ethnicities and geographical regions, for example, F508del is found in $70 \%$ of patients with $\mathrm{CF}$, but its incidence varies widely between ethnic groups [2].

According to chloride transport dysfunction, the CFTR pathogenic variants can be grouped into five classes: (I) CFTR not synthesized, (II) defective processing, (III) defective regulation, (IV) defective conductance, (V) partially defective production or processing. This classification makes it possible to predict the likely effect of a known pathogenic variant on the CFTR function, although the effect of a given pathogenic variant on cell function may not be known in full [3].

A complex relationship was observed between the CF phenotype and the CFTR genotype. Generally, genotypes consisting of two severe pathogenic variants (classes IIII) were associated with more severe CF phenotype than genotypes with at least one mild pathogenic variant (class IV or V) [4].

Limited data are available regarding CF prevalence among Syrian children. It is expected that cystic fibrosis is rare in Syria as in other Middle Eastern countries; only few articles suggested its presence $[5,6]$.

This study aims to point on the diagnostic, clinical, and genetic characteristics of cystic fibrosis patients in Syria and to assess the relationship between genotype and phenotype in these patients.

\section{Methods}

This is a retrospective study. It included the data of 300 patients out of 464 who were clinically suspected of having CF and were referred to the children's hospital of Damascus throughout a 10-year period from January 2007 to December 2017. Data were collected from medical records.

The disease was confirmed in 173 children by the presence of a confirmed value of the sweat chloride test with/without two pathogenic variants in addition to having a clinical standard-in at least one system-which suggests the diagnosis of CF according to the most recent guidelines (consensus guidelines on the diagnosis of cystic fibrosis 2017 from the fibrosis foundation).

The relationship between genotype and phenotype was evaluated in 85 children who had two pathogenic variants.

Sweat chloride test was done for all patients included in the study (173 patients) using the standard pilocarpine iontophoresis for sweating induction and ion selective electrode for measuring chloride ion concentrations in sweat.
Reference values of quantitative chloride analysis are as follows: $<30 \mathrm{mmol} / \mathrm{L}=$ negative, $30-60 \mathrm{mmol} / \mathrm{L}=$ borderline, $\geqslant 60 \mathrm{mmol} / \mathrm{L}=$ positive. Cystic fibrosis pathogenic variant analysis was done for 127 patients while 46 patients did not undergo the test due to shortage of test kits during their hospitalization. This test was performed by using a reverse dot-blot method. Kits from two companies were used (as shown in Tables 1 and 2).

Results were analyzed using SPSS version 23. Data was summarized using mean, standard deviation, numbers, and percentages for different variables.

Comparison between groups was performed using Fisher's exact or chi-square tests which are suitable for the categorical variables. $P$ values of $<0.05$ were considered to be statistically significant.

\section{Results}

The number of cases suspected with cystic fibrosis in the Children's Hospital of Damascus ranges between 25 and 50 new cases annually, and the confirmed prevalence of disease is estimated at approximately 2.5 per 1000 inpatient children.

The present study enrolled 173 Syrian children with clinical symptoms suggestive of $\mathrm{CF}$ in addition to having a positive sweat test and/or a positive result of CF pathogenic variant analysis (Fig. 1).

Patient's age ranged between 2 days and 10 years (17.4 \pm 30.9 months); CF diagnosis was established in the present study by the age of 1 year in 136 patients (78.6\%). Ninety-two patients $(53.2 \%)$ of them were females, and eighty-one $(46.8 \%)$ were males. Consanguinity was reported in $75.7 \%$ of the families. Family history was positive in 27 cases (15.6\%). The mortality rate was $23.1 \%$ ( 40 cases); 21 cases were due to septic shock as a result of pulmonary bronchitis, 11 cases were due to meconium ileus, 7 cases were due to malnutrition, and one case was due to cirrhosis. The respiratory symptoms were observed in 141 cases (81.5\%), and the gastrointestinal symptoms were observed in 133 cases (76.9\%) (Table 3).

Eighteen pathogenic variants, 13 pathogenic substitution variants, and 5 pathogenic deletion variants distributed over different exons and introns were detected in 183 mutant alleles out of 254 examined alleles (Fig. 2).

The result of sweat chloride test was high $(\geq 60)$ in 40 cases. $47.1 \%$ of whom the CF pathogenic variant analysis showed two pathogenic variants, borderline [30-59] in 34 cases $(40 \%)$, and low in 11 cases (12.9\%) (Table 4).

Table 5 shows the clinical and genetic characteristics of patients in the studied sample.

The relationship between the pathogenic variant classes and clinical characteristics in patients with two pathogenic variants were tested and distributed as shown 
Table 1 Pathogenic variants that were analyzed by the different INNO-LIPA CFTR kits from Innogenetics, Ghent, Belgium company

\begin{tabular}{|c|c|c|c|c|c|}
\hline \multicolumn{3}{|c|}{ INNO-LIPA CFTR19 kit } & \multicolumn{3}{|c|}{ INNO-LIPA CFTR 17+ Tn kit } \\
\hline F508del & W1282X & G551D & $621+1 G>T$ & $3849+10 K b C>T$ & R117H \\
\hline G542X & $1717-1 G>A$ & R533X & $2183 A A>G$ & $2789+5 G>A$ & R334W \\
\hline N1303K & $1898+1 G>A$ & CFTRdel2-3 & 394delTT & $R 1162 X$ & R347P \\
\hline $711+1 G>T$ & 1507del & R560T & 3659delC & G85E & 1078delT \\
\hline 3905inst & $3272-26 A>G$ & S1251N & A455E & 2143delT & E60X \\
\hline 1148T & 3199del6 & $3120+1 G>A$ & 2184delA & Tn polymorphism in 8 intron & $711+5 G>A$ \\
\hline Q552X & & & & & \\
\hline
\end{tabular}

in Table 6. Table 7 shows the $\mathrm{P}$ values of the comparison groups.

P1 values, to compare the group of patients with two class I pathogenic variants and the group with two-class $(\mathrm{IV}, \mathrm{V})$ pathogenic variants. P2 values, to compare the group of patients with two class I pathogenic variants and the group with two pathogenic variants: one of class I/II and the other of class IV/V. P3 values, to compare the group of patients with two class II pathogenic variants (deletion pathogenic variants) and the group with two-class (IV, V) pathogenic variants. P4 values, to compare the group of patients with two class II pathogenic variants (pathogenic deletion variants) and the group with two pathogenic variants: one of class I/II and the other of class IV/V. P5 values, to compare the group of patients with two class II pathogenic variants (pathogenic substitution variants) and the group with two class (IV, V) pathogenic variants. P6 values, to compare the group of patients with two class II pathogenic variants (pathogenic substitution variants) and the group with two pathogenic variants: one of class (I/II) and the other of class (IV/V)

A statistical difference was observed when studying the incidence of steatorrhea between the group of patients with two class I pathogenic variant and patients with two-class (IV, V) pathogenic variants $(68.4 \%$ and $1.11 \%$, respectively; $P$ value $<0.013$ ), as well as between the group of patients with two class I pathogenic variant and patients with two pathogenic variants [one of class (I/II) and the other of class (IV/V) [(68.4\%, 0\%, respectively; $p$ value $<0.011)$ ]], and this difference was not noticed when studying the relationship in the presence of class II pathogenic variants (deletion or substitution). However, the incidence of steatorrhea was higher compared to its incidence in patients who had two-class (IV, $\mathrm{V})$ pathogenic variants.

There were no significant statistical differences between the studied groups when studying other clinical characteristics. However, the incidence of failure to thrive, recurrent respiratory and pulmonary infections, meconium ileus, and hepatic disease was higher in patients who had two-class (I/II/III) pathogenic variant on CFTR gene compared to patients who had at least oneclass (IV/V) pathogenic variant.

A statistical difference was also observed when studying the incidence of mortality between the group of patients who had two pathogenic variants class II (pathogenic deletion variant) and the group of patients with two pathogenic variant classes (IV, V) (38.9\% and $0 \%$, respectively; $\mathrm{p}$ value $<0.04)$. The mortality rate in patients with two pathogenic variant classes (I/II/III) is higher compared to patients with at least one pathogenic variant class $(\mathrm{IV} / \mathrm{V})$.

\section{Discussion}

In the developing countries, CF had remained largely unrecognized. Its clinical features resemble those of other diseases such as pneumonia, bronchiectasis, asthma, failure to thrive, and celiac disease in addition to a high infant mortality rate. Therefore, the diagnosis of CF can be missed due to a low index of suspicion [7].

In the present study, only $47.1 \%$ of patients who had two pathogenic variants on CFTR gene had positive results with sweat chloride test. This may suggest the

Table 2 Pathogenic variants that were analyzed by a kit from ViennaLab Diagnostics GmbH, Austria

\begin{tabular}{|c|c|c|c|c|c|}
\hline \multicolumn{3}{|l|}{ Strip A } & \multicolumn{3}{|l|}{ Strip B } \\
\hline F508del & W1282X & G551D & $621+1 G>T$ & $711+1 G>T$ & R117H \\
\hline G542X & $1717-1 G>A$ & R533X & $3272-26 A>G$ & $1898+1 G>A$ & Y1092X \\
\hline N1303K & 2143delT & $2183 A A>G$ & R347H & $Y 122 \times 621+1 \quad G>T$ & 394delTT \\
\hline 2184insA & $R 1162 X$ & R560T & G85E & $3849+10 K b C>T$ & R117H \\
\hline $2789+5 G>A$ & 3659 delC & 3905inst & R334W & $R 347 P$ & 1078delT \\
\hline 2184delA & 1507del & CFTRdel2-3 & A455E & Tn polymorphism in 8 intron & \\
\hline
\end{tabular}




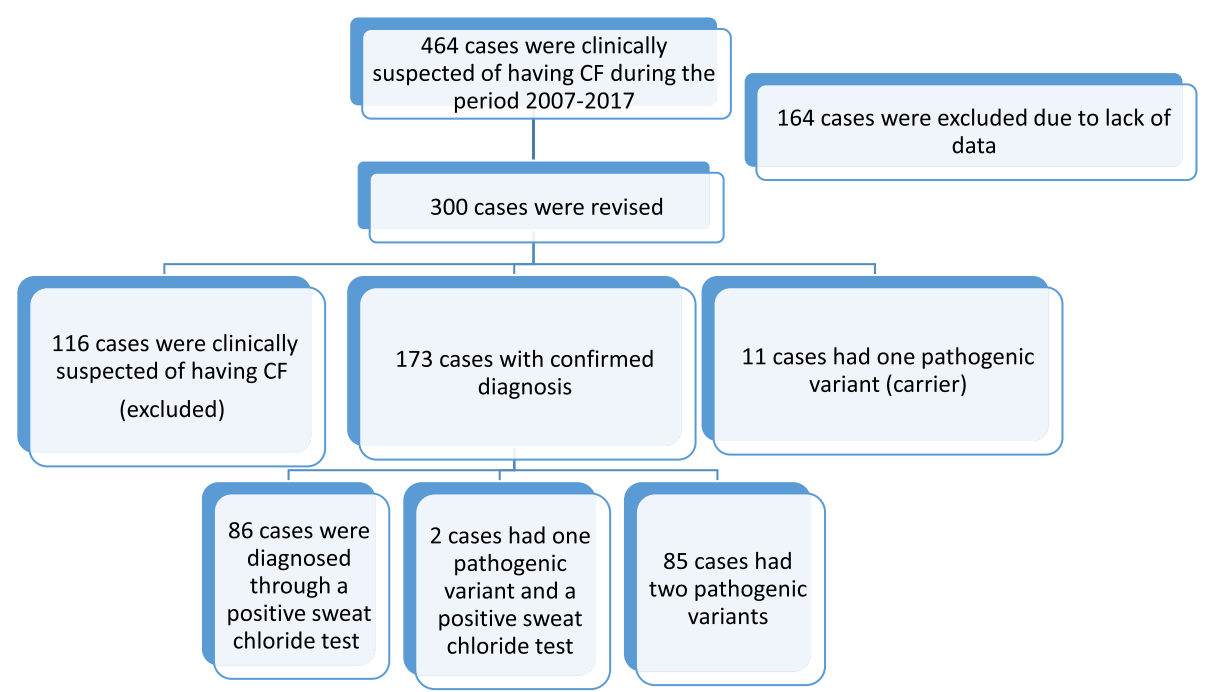

Fig. 1 Flow chart of study identification and inclusion and exclusion criteria

Table 3 The demographic and clinical data of the studied sample

\begin{tabular}{|c|c|c|c|c|}
\hline \multicolumn{5}{|l|}{$\mathrm{N}=173$} \\
\hline \multirow[t]{2}{*}{ Gender } & \multicolumn{2}{|l|}{$\begin{array}{l}\text { Female } \\
\mathrm{n}=92\end{array}$} & \multicolumn{2}{|l|}{$\begin{array}{l}\text { Male } \\
\mathrm{n}=81\end{array}$} \\
\hline & \multicolumn{2}{|l|}{$53.2 \%$} & \multicolumn{2}{|l|}{$46.8 \%$} \\
\hline \multirow[t]{2}{*}{ Age at diagnosis (months) } & $\begin{array}{l}>36 \\
N=21\end{array}$ & $\begin{array}{l}{[12-36]} \\
N=16\end{array}$ & $\begin{array}{l}{[2-12]} \\
N=105\end{array}$ & $\begin{array}{l}\leq 2 \\
N=31\end{array}$ \\
\hline & $12.1 \%$ & $9.2 \%$ & $60.7 \%$ & $17.9 \%$ \\
\hline Consanguinity & \multicolumn{4}{|l|}{$\mathrm{N}=131(75.7 \%)$} \\
\hline Family history & \multicolumn{4}{|l|}{$\mathrm{N}=27(15.6 \%)$} \\
\hline Mortality & \multicolumn{4}{|l|}{$\mathrm{N}=40(23.1 \%)$} \\
\hline \multirow{2}{*}{$\begin{array}{l}\text { The gastrointestinal manifestations } \\
\mathrm{N}=133 \\
(76.9 \%)\end{array}$} & $\begin{array}{l}\text { Steatorrhea } \\
\mathrm{N}=60\end{array}$ & $\begin{array}{l}\text { Chronic diarrhea } \\
\mathrm{N}=81\end{array}$ & & $\begin{array}{l}\text { Meconium ileus/intestinal obstruction } \\
\mathrm{N}=36\end{array}$ \\
\hline & $34.7 \%$ & $46.8 \%$ & & $20.8 \%$ \\
\hline The respiratory diseases & \multicolumn{4}{|l|}{$\mathrm{N}=141(81.5 \%)$} \\
\hline Bronchitis & \multicolumn{4}{|l|}{$\mathrm{N}=65(37.6 \%)$} \\
\hline Recurrent respiratory infection & \multicolumn{4}{|l|}{$\mathrm{N}=68(39.3 \%)$} \\
\hline Wheeze & \multicolumn{4}{|l|}{$\mathrm{N}=95(54.9 \%)$} \\
\hline Chronic cough & \multicolumn{4}{|l|}{$N=114(65.9 \%)$} \\
\hline \multirow[t]{2}{*}{ Mean age at onset of symptoms (months) } & \multicolumn{2}{|c|}{ The gastrointestinal manifestations } & \multicolumn{2}{|c|}{ The respiratory manifestations } \\
\hline & \multicolumn{2}{|l|}{$3.4 \pm 8.5$} & \multicolumn{2}{|c|}{$7.8 \pm 17.4$} \\
\hline Liver disease & \multicolumn{4}{|l|}{$\mathrm{N}=41(23.7 \%)$} \\
\hline Severe metabolic alkalosis $\mathrm{PH}>=6$ & \multicolumn{4}{|l|}{$\mathrm{N}=71(41 \%)$} \\
\hline Low chloride metabolic alkalosis & \multicolumn{4}{|l|}{$\mathrm{N}=55(31.8 \%)$} \\
\hline $\begin{array}{l}\text { Pseudomonas aeruginosa in bronchial } \\
\text { secretions }\end{array}$ & \multicolumn{4}{|l|}{$\mathrm{N}=12(6.9 \%)$} \\
\hline Digital clubbing & \multicolumn{4}{|l|}{$\mathrm{N}=12(6.9 \%)$} \\
\hline Salty sweating & \multicolumn{4}{|l|}{$\mathrm{N}=12(6.9 \%)$} \\
\hline Failure to thrive & \multicolumn{4}{|l|}{$N=106(61.3 \%)$} \\
\hline The average length of hospital stay & \multicolumn{4}{|l|}{$16.1 \pm 10.6$} \\
\hline
\end{tabular}




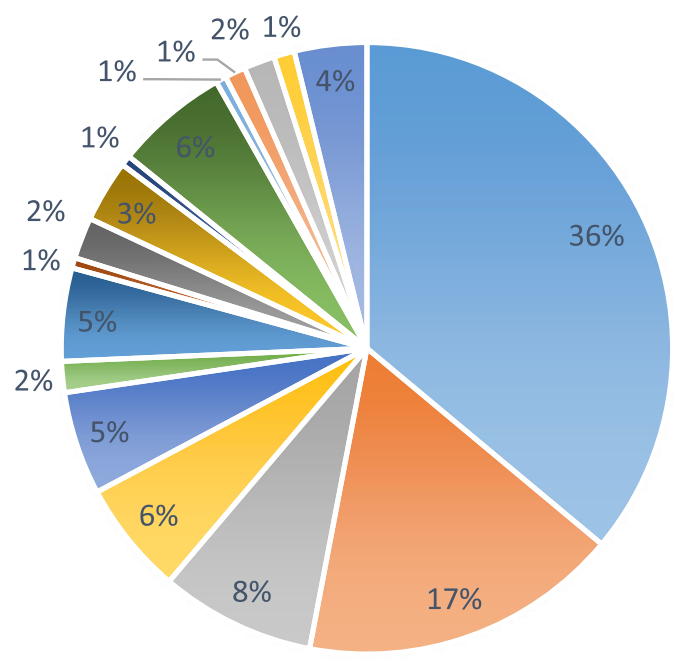

$$
\begin{aligned}
& =\text { F508del } \\
& =\text { W1282X } \\
& =\text { N1303K } \\
& =\text { G85E } \\
& =3199 \text { del6 / I148T } \\
& =\text { G551D } \\
& =\text { CFTR del2-3 } \\
& =2789+5 G>A \\
& =\text { R1162X } \\
& =\text { R334W } \\
& =2184 d e l A \\
& =\text { R347P } \\
& =3849+10 \mathrm{~Kb} C>T \\
& =\text { G542X } \\
& =2183 A A>G \\
& =394 d e l T T \\
& =1898+1 G>A
\end{aligned}
$$

Fig. 2 The incidence of CFTR pathogenic variants detected in the studied sample

importance of CF pathogenic variant analysis to confirm the incidence of clinical suspicion regardless of the sweat chloride values, as well as the importance of assessing the validity of the criteria and procedures which were followed during testing such as the amount of sweat taken, the method of sampling, and the conditions that must be present in the child, which were difficult to assess in this retrospective study.

CF diagnosis was established in the present study by the age of 1 year in 136 patients (78.6\%). According to the annual report of the CF foundation in the USA-included 880 patients diagnosed in 2017-the majority of cases $(66.6 \%)$ were diagnosed by the same age [8]. As for the countries of Middle East, El-Falaki and colleagues diagnosed $33.3 \%$ of their patients in the first year of life [7]. In a study in Bahrain in 1998 (Al-Mahroos) including 25 patients, one of them is of Syrian origin [9], the disease was diagnosed in all patients in the first year of life, and this was due to the classical manifestation that appeared on patients at an early age, not as a result of good awareness, and this may explain the high incidence in this study as well.

In this study, the mortality rate was $23.1 \%$ (40 patients); $82.5 \%$ of them (33 patients) died in the first year of life, and it is likely to be higher if the rest of the survived cases were followed. The mortality rate in a study including 32 Tunisian patients (Boussetta and colleagues) was $50 \%$; $40 \%$ of them died in the first year of life [10]. However, in Rafeey and colleagues' study which was done in Turkey in 2017 and included 210 patients, the mortality rate was $12.3 \% ; 3.8 \%$ of them died in the first year of life [11]. According to the CF's 2017 annual report which included 29,887 patients, the mortality rate was $1.3 \%$ with an average age of 30.6 years [8]. The reason for the high mortality rates of cystic fibrosis patients in childhood in Arab countries may be due to a lack of studies and awareness about the disease and a lack of their own care centers, unlike Turkey (Middle East Cystic Fibrosis Association) and the western countries (CF Foundation).

Due to genetic and environmental differences among ethnic groups, CF presentation may vary between populations. According to the results collected in this study, the incidence of respiratory symptoms was $81.5 \%$ with an average age of $17.4 \pm 7.8$ months, and the gastrointestinal symptoms was $76.9 \%$ with an average age of $3.4 \pm$ 8.5 months, while in the study of Jarjour and colleagues in 2015 [5] which occurred on 25 Syrian patients, the rates reached to $64 \%$ and $60 \%$ respectively.

In this study, the incidence of meconium ileus (20.8\%) is higher than its incidence in other studies. According to the CF's 2017 annual report, it was 9.6\%, while in Arab studies it was noted as the following:

El-Falaki and colleagues [7] (2.85\%), Rawashdeh and Manal in 2000 (6.6\%) [12], Boussetta and colleagues (17\%) [10], while in the study of Mahroos [9] it reached to $20 \%$.

This high incidence may be due to the concentration of most of the detected pathogenic variants in classes I and II, which causes the loss of whole protein or its function and may lead to more severe clinical symptoms, as well as the genetic modification in other genes can play an important role in the emergence of this symptom [13].

Steatorrhea is a late sign which can be used to confirm pancreatic insufficiency; it predicts a decrease in pancreatic function by $80 \%$ [14]. Pancreatic insufficiency is one of the most common gastrointestinal manifestations in 
Table 4 CFTR pathogenic variants that were detected in the sample, its classifications, the result of sweat chloride test, and the age at diagnosis

\begin{tabular}{|c|c|c|c|c|c|c|}
\hline $\begin{array}{l}\text { Number of } \\
\text { patients }\end{array}$ & $\begin{array}{l}\text { The pathogenic } \\
\text { variant on the first } \\
\text { allele }\end{array}$ & $\begin{array}{l}\text { The first } \\
\text { pathogenic } \\
\text { variant class }\end{array}$ & $\begin{array}{l}\text { The pathogenic variant } \\
\text { on the second allele }\end{array}$ & $\begin{array}{l}\text { The second } \\
\text { pathogenic variant } \\
\text { class }\end{array}$ & $\begin{array}{l}\text { Sweat chloride } \\
\text { values (mmol/l) }\end{array}$ & $\begin{array}{l}\text { Age at } \\
\text { diagnosis } \\
\text { (months) }\end{array}$ \\
\hline 14 & W1282X & I & W1282X & 1 & $58 \pm 42$ & $5.3 \pm 3.8$ \\
\hline 1 & W1282X & I & R1162X & I & 60 & 3 \\
\hline 1 & $R 1162 X$ & । & $R 1162 X$ & I & 120 & 2.5 \\
\hline 1 & $2183 A A>G$ & I & $2183 A A>G$ & I & 50 & 30 \\
\hline 1 & 394delTT & I & 394delTT & । & 57 & 83 \\
\hline 1 & G542X & । & G542X & I & 60 & 42 \\
\hline 1 & W1282X & I & F508del & ॥ & 65 & 4 \\
\hline 1 & $2183 A A>G$ & । & N1303K & $\|$ & 61 & 7 \\
\hline 3 & CFTRdel2-3 & I & G551D & III & $84 \pm 8$ & $4 \pm 1$ \\
\hline 1 & W1282X & I & R334W & IV & 96 & 2 \\
\hline 2 & CFTRdel2-3 & । & R347P & IV & $28 \pm 5$ & $7 \pm 6$ \\
\hline 1 & CFTRdel2-3 & I & R334W & IV & 89 & 6 \\
\hline 1 & CFTRdel2-3 & I & $3849+10 K b \mathrm{C}>T$ & V & 25 & 11 \\
\hline 5 & 3199 del 6/1148T & II/polymorphism & 3199 del 6//148T & II/polymorphism & $61 \pm 26$ & $7 \pm 5$ \\
\hline 31 & F508del & $\|$ & F508del & $\|$ & $58 \pm 25$ & $19 \pm 35$ \\
\hline 1 & F508del & $\|$ & N1303K & $\|$ & 60 & 3 \\
\hline 4 & G85E & $\|$ & G85E & ॥ & $47 \pm 15$ & $4 \pm 1$ \\
\hline 6 & N1303K & $\|$ & N1303K & ॥ & $70 \pm 23$ & $30 \pm 47$ \\
\hline 1 & R334W & IV & R347P & IV & 35 & 1 \\
\hline 4 & R347P & IV & R347P & IV & $53 \pm 29$ & $2.5 \pm 1$ \\
\hline 3 & $1898+1 G>A$ & V & $1898+1 G>A$ & V & $68 \pm 39$ & $9 \pm 2.5$ \\
\hline 1 & R334W & IV & $1898+1 G>A$ & V & 100 & 100 \\
\hline 2 & CFTRdel2-3 & I & - & - & $33 \pm 00$ & $5.5 \pm 0.3$ \\
\hline 1 & N1303K & $\|$ & - & - & 60 & 3 \\
\hline 1 & $R 1162 X$ & I & - & - & 55 & 95 \\
\hline 2 & F508del & $\|$ & - & - & $45 \pm 2$ & $10 \pm 12$ \\
\hline 1 & $2789+5 G>A$ & V & - & - & 85 & 3 \\
\hline 1 & 2184delA & I & - & - & 35 & 1 \\
\hline 2 & R334W & IV & - & - & 18.5 & $34 \pm 37$ \\
\hline 3 & G85E & $\|$ & - & - & 50 & $2.8 \pm 0.3$ \\
\hline
\end{tabular}

CF patients. It affects about $85 \%$ of them at a certain stage of their life [14]; in this study, the incidence of steatorrhea was $34.7 \%$, which may be low compared to the expected incidence, but this may be due to the young age of studied patients, the design of this study, and failure to do all analysis that were necessary for the evaluation.

In this study, $61.3 \%$ of patients had failure to thrive. This result was similar to that of Jarjour and colleagues in 2015 , where the incidence reached to $60 \%$. The incidence of failure to thrive in Arab studies is high. In the study of El-Falaki and colleagues in 2014, the rate reached to 56\%. In Rawashdeh and Manal's study (2000), the incidence was 75.4\%. The CF's 2017 annual report indicated that $6.9 \%$ of CF patients had failure to thrive; this small percentage may be due to starting to give the appropriate food and pancreatic enzymes replacement at an early age.

The highest incidence of failure to thrive was observed in other governorates-and its countryside-(62.3\%), followed by Damascus countryside (26.4\%). This can be attributed to a lack of awareness about disease and a decline in living conditions in those areas. Good growth curves have a role to reduce the incidence of chronic respiratory symptoms as a recurrent cough [15]; it was observed in this study that $79.2 \%$ of cases of growth failure 
Table 5 Clinical and genetic characteristics of patients in the studied sample

\begin{tabular}{|c|c|c|c|c|c|c|c|c|c|c|}
\hline $\begin{array}{l}\text { Pathogenic } \\
\text { variant }\end{array}$ & $\mathrm{N}$ & $\begin{array}{l}\text { Meconium } \\
\text { ileus (MI) }\end{array}$ & $\begin{array}{l}\text { Recurrent } \\
\text { respiratory } \\
\text { infections }\end{array}$ & Bronchitis & $\begin{array}{l}\text { Pancreatic } \\
\text { insufficiency } \\
\text { (PI) }\end{array}$ & Steatorrhea & $\begin{array}{l}\text { Failure } \\
\text { to thrive }\end{array}$ & $\begin{array}{l}\text { Liver } \\
\text { disease }\end{array}$ & $\begin{array}{l}\text { Chronic } \\
\text { diarrhea }\end{array}$ & Mortality \\
\hline $\begin{array}{l}\text { W1282XI } \\
\text { W1282X }\end{array}$ & 14 & $42.6 \%(6)$ & $50 \%(7)$ & $35.7 \%(5)$ & $7.1 \%(1)$ & $64.3 \%(9)$ & $64.3 \%(9)$ & $\begin{array}{l}28.6 \% \\
(4)\end{array}$ & $42.6 \%(6)$ & $35.7 \%(5)$ \\
\hline W1282X/R1162X & 1 & & & & & Yes & Yes & & Yes & \\
\hline$R 1162 X / R 1162 X$ & 1 & Yes & Yes & & & Yes & Yes & & & \\
\hline $\begin{array}{l}2183 A A>G / \\
2183 A A>G\end{array}$ & 1 & Yes & Yes & Yes & Yes & Yes & Yes & Yes & Yes & Yes \\
\hline $\begin{array}{l}\text { 394delTT/ } \\
\text { 394delTT }\end{array}$ & 1 & & Yes & Yes & Yes & Yes & Yes & Yes & Yes & \\
\hline G542X/G542X & 1 & Yes & & & & & & Yes & Yes & \\
\hline W1282X/F508del & 1 & & Yes & & & & Yes & & & \\
\hline $\begin{array}{l}2183 A A>G / \\
\text { N1303K }\end{array}$ & 1 & & Yes & Yes & & & & & & Yes \\
\hline $\begin{array}{l}\text { CFTRdel2-3/ } \\
\text { G551D }\end{array}$ & 3 & & $100 \%(3)$ & & & & $33.3 \%(1)$ & $\begin{array}{l}33.3 \% \\
(1)\end{array}$ & & \\
\hline W1282X/R334W & 1 & & Yes & Yes & Yes & & & Yes & & Yes \\
\hline $\begin{array}{l}\text { CFTRdel2-3/ } \\
\text { R347P }\end{array}$ & 2 & & $33.3 \%(1)$ & $33.3 \%(1)$ & & & & & $33.3 \%(1)$ & \\
\hline $\begin{array}{l}\text { CFTRdel2-3/ } \\
\text { R334W }\end{array}$ & 1 & & Yes & & & & Yes & & & \\
\hline $\begin{array}{l}\text { CFTRdel2-3/ } \\
3849+10 \mathrm{~Kb} C>T\end{array}$ & 1 & Yes & & & & & Yes & Yes & Yes & \\
\hline $3199 \mathrm{del} 6 / 1148 \mathrm{~T}$ & 5 & & $60 \%(3)$ & $60 \%(3)$ & & $40 \%(2)$ & $60 \%(3)$ & $20 \%(1)$ & $40 \%(2)$ & $60 \%(3)$ \\
\hline F508del/F508del & 31 & $22.6 \%(7)$ & $54.8 \%(17)$ & $16.1 \%(5)$ & $3.2 \%(1)$ & 29\% (9) & $54.8 \%(17)$ & 29\% (9) & $38.7 \%(12)$ & $\begin{array}{l}35.3 \% \\
(11)\end{array}$ \\
\hline F508del/N1303K & 1 & & & & & & Yes & & & \\
\hline G85E/G85E & 4 & $25 \%(1)$ & $75 \%(3)$ & $75 \%(3)$ & & $25 \%(1)$ & $75 \%(3)$ & & $25 \%(1)$ & $25 \%(1)$ \\
\hline N1303K/N1303K & 6 & $66.7 \%(4)$ & $33.3 \%(2)$ & $50 \%(3)$ & & $33.3 \%(2)$ & $50 \%(3)$ & $\begin{array}{l}16.7 \% \\
(1)\end{array}$ & (3) $\% 50$ & $50 \%(3)$ \\
\hline R334W/R347P & 1 & & Yes & & & & & & & \\
\hline R347P/R347P & 4 & & $100 \%(4)$ & & & $25 \%(1)$ & $50 \%(2)$ & $25 \%(1)$ & $100 \%(4)$ & \\
\hline $\begin{array}{l}1898+1 G>A / \\
1898+1 G>A\end{array}$ & 3 & $33.3 \%(1)$ & $66.6 \%(2)$ & $33.3 \%(1)$ & $33.3 \%(1)$ & & $100 \%(3)$ & & & \\
\hline $\begin{array}{l}1898+1 G>A / \\
R 334 W\end{array}$ & 1 & & & Yes & Yes & & & & & \\
\hline CFTRdel2-3/- & 2 & & & $50 \%(1)$ & & $50 \%(1)$ & $50 \%(1)$ & $50 \%(1)$ & $50 \%(1)$ & $100 \%(2)$ \\
\hline N1303K/- & 1 & & & & & Yes & & Yes & Yes & \\
\hline R1162X/- & 1 & Yes & Yes & & & Yes & Yes & & Yes & \\
\hline F508del/- & 2 & & $50 \%(1)$ & & & $100 \%(2)$ & $100 \%(2)$ & $50 \%(1)$ & $100 \%(2)$ & \\
\hline $2789+5 G>A /-$ & 1 & & Yes & & & Yes & & & & \\
\hline 2184delA/- & 1 & Yes & Yes & & & & & & Yes & \\
\hline R334W/- & 2 & & $100 \%(2)$ & & & & & & $50 \%(1)$ & \\
\hline G85E/- & 3 & & $66.6 \%(2)$ & & & $33.3 \%(1)$ & $100 \%(3)$ & & $66.6 \%(2)$ & \\
\hline
\end{tabular}

(84 cases) were associated with chronic respiratory symptoms.

Clinical phenotypes reported in studies from other populations in the Middle East suggest a relatively high incidence of hepatobiliary manifestations (jaundice, hepatomegaly, or cholelithiasis) in CF patients. Hepatobiliary involvement was reported in 4 to $10.9 \%$ of Middle Eastern patients diagnosed with CF [7]. In the present study, $23.7 \%$ of patients had hepatobiliary manifestations; this incidence of hepatobiliary involvement is 
Table 6 The relationship between the pathogenic variant classes and clinical characteristics in CF patients in the studied sample

\begin{tabular}{|c|c|c|c|c|c|c|}
\hline $\mathrm{N}=85$ & $\begin{array}{l}\text { Two-class (IV/ } \\
\text { V) pathogenic } \\
\text { variants } \\
\mathrm{N}=9\end{array}$ & $\begin{array}{l}\text { One-class (I) pathogenic } \\
\text { variant + one-class (IV/V) } \\
\text { pathogenic variant } \\
\mathrm{N}=5\end{array}$ & $\begin{array}{l}\text { *Two pathogenic } \\
\text { variants of different } \\
\text { classes of I, II, III } \\
\mathrm{N}=6\end{array}$ & $\begin{array}{l}* * \text { Two class II } \\
\text { pathogenic } \\
\text { variants } \\
\mathrm{N}=10\end{array}$ & $\begin{array}{l}* * * \text { Two class } \\
\text { II pathogenic } \\
\text { variants } \\
\mathrm{N}=36\end{array}$ & $\begin{array}{l}\text { Two class I } \\
\text { pathogenic } \\
\text { variants } \\
\mathrm{N}=19\end{array}$ \\
\hline \multirow{2}{*}{$\begin{array}{l}\text { Mean age at diagnosis } \\
\text { (months) }\end{array}$} & $N=14$ & & $N=71$ & & & \\
\hline & $18.1 \pm 32.6$ & $5.6 \pm 4.6$ & $15.1 \pm 32.5$ & $16.3 \pm 34.6$ & $18.3 \pm 34.1$ & $15 \pm 25.5$ \\
\hline \multirow[t]{2}{*}{ Mortality } & $\mathrm{N}=0(0 \%)$ & $\mathrm{N}=1(10 \%)$ & $\mathrm{N}=1(16.7 \%)$ & $\mathrm{N}=4(40 \%)$ & $\mathrm{N}=14$ (38.9\%) & $\mathrm{N}=6$ (31.6\%) \\
\hline & $\mathrm{N}=1$ (7.1\%) & & $\mathrm{N}=25(35.2 \%)$ & & & \\
\hline $\begin{array}{l}\text { Mean age at onset of } \\
\text { gastrointestinal } \\
\text { symptoms (months) }\end{array}$ & $5.6 \pm 10.3$ & $1.2 \pm 1.8$ & No symptoms & $9.7 \pm 18.8$ & $2.2 \pm 2.3$ & $1.2 \pm 1.6$ \\
\hline \multirow[t]{2}{*}{ Chronic diarrhea } & $\mathrm{N}=4(44.4 \%)$ & $\mathrm{N}=2(40 \%)$ & $\mathrm{N}=0(0 \%)$ & $\mathrm{N}=4(40 \%)$ & $\mathrm{N}=14$ (38.9\%) & $\mathrm{N}=10(52.6 \%)$ \\
\hline & $\mathrm{N}=6(42.8 \%)$ & & $\mathrm{N}=28(39.4 \%)$ & & & \\
\hline \multirow[t]{2}{*}{ Meconium ileus } & $\mathrm{N}=1(11.1 \%)$ & $N=1(10 \%)$ & $\mathrm{N}=0(0 \%)$ & $\mathrm{N}=5(50 \%)$ & $\mathrm{N}=7(19.4 \%)$ & $\mathrm{N}=9$ (47.4\%) \\
\hline & $\mathrm{N}=2(14.3 \%)$ & & $N=21(29.6 \%)$ & & & \\
\hline \multirow[t]{2}{*}{ Liver disease } & $\mathrm{N}=1(11.1 \%)$ & $\mathrm{N}=2(40 \%)$ & $\mathrm{N}=1(16.7 \%)$ & $\mathrm{N}=1(10 \%)$ & $\mathrm{N}=10(27.8 \%)$ & $\mathrm{N}=7$ (36.8\%) \\
\hline & $\mathrm{N}=3(21.4 \%)$ & & $\mathrm{N}=19(26.8 \%)$ & & & \\
\hline \multirow[t]{2}{*}{ Steatorrhea } & $\mathrm{N}=1(11.1 \%)$ & $\mathrm{N}=0(0 \%)$ & $\mathrm{N}=0(0 \%)$ & $\mathrm{N}=3(30 \%)$ & $\mathrm{N}=11$ (30.5\%) & $\mathrm{N}=13(68.4 \%)$ \\
\hline & $\mathrm{N}=1(7.1 \%)$ & & $\mathrm{N}=27(38 \%)$ & & & \\
\hline $\begin{array}{l}\text { Mean age at onset of } \\
\text { respiratory disease } \\
\text { (months) }\end{array}$ & $7.2 \pm 9.3$ & $4.9 \pm 4.4$ & $5.7 \pm 6$ & $3 \pm 2.1$ & $2.9 \pm 2.3$ & $15 \pm 26$ \\
\hline \multirow{2}{*}{$\begin{array}{l}\text { Recurrent respiratory } \\
\text { infections }\end{array}$} & $\mathrm{N}=2(22.2 \%)$ & $\mathrm{N}=3(60 \%)$ & $\mathrm{N}=3(50 \%)$ & $\mathrm{N}=4(40 \%)$ & $\mathrm{N}=15$ (41.7\%) & $\mathrm{N}=6$ (31.6\%) \\
\hline & $\mathrm{N}=5(35.7 \%)$ & & $N=28(39.4 \%)$ & & & \\
\hline \multirow[t]{2}{*}{ Bronchitis } & $\mathrm{N}=2(22.2 \%)$ & $\mathrm{N}=2(20 \%)$ & $\mathrm{N}=1(16.7 \%)$ & $\mathrm{N}=6(60 \%)$ & $\mathrm{N}=8(22.2 \%)$ & $\mathrm{N}=7$ (36.8\%) \\
\hline & $\mathrm{N}=4(28.6 \%)$ & & $\mathrm{N}=22(31 \%)$ & & & \\
\hline \multirow[t]{2}{*}{ Failure to thrive } & $\mathrm{N}=5(55.5 \%)$ & $\mathrm{N}=2(40 \%)$ & $\mathrm{N}=3(50 \%)$ & $\mathrm{N}=6(60 \%)$ & $\mathrm{N}=20$ (55.5\%) & $\mathrm{N}=13(68.4 \%)$ \\
\hline & $\mathrm{N}=7(50 \%)$ & & $\mathrm{N}=42(59.1 \%)$ & & & \\
\hline $\begin{array}{l}\text { The average length of } \\
\text { hospital stay }\end{array}$ & $17.7 \pm 11.8$ & $10.2 \pm 9.9$ & $14 \pm 9$ & $13.2 \pm 3.3$ & $19 \pm 14.1$ & $16.3 \pm 9.7$ \\
\hline
\end{tabular}

*F508del+N1303K, CFTRdel2-3 +G551D,2183 AA>G+N1303K, F508del+W1282X

**Pathogenic substitution variants

***Pathogenic deletion variants

Table $7 \mathrm{P}$ values of the comparison groups to determine the relationship between the incidence of different clinical characteristics and the pathogenic variant classes

\begin{tabular}{|c|c|c|c|c|c|c|}
\hline & P1 values & P2 values & P3 values & P4 values & P5 values & P6 values \\
\hline Mortality & 0.136 & 1 & 0.04 & 0.64 & 0.087 & 0.6 \\
\hline Chronic diarrhea & 1 & 1 & 1 & 1 & 1 & 1 \\
\hline Meconium ileus & 0.098 & 0.36 & 1 & 1 & 0.14 & 0.58 \\
\hline Liver injury & 0.21 & 0.63 & 0.42 & 1 & 1 & 1 \\
\hline steatorrhea & 0.013 & 0.011 & 0.4 & 0.3 & 0.58 & 0.5 \\
\hline Recurrent respiratory infections & 1 & 0.33 & 0.45 & 0.64 & 0.63 & 0.6 \\
\hline Bronchitis & 0.67 & 0.63 & 1 & 1 & 0.17 & 0.28 \\
\hline Failure to thrive & 0.68 & 1 & 1 & 1 & 1 & 1 \\
\hline
\end{tabular}


much higher than that reported in the CF's 2017 annual report $(2.1 \%)$. Hepatic disease was represented by elevated hepatic yeasts (AST, ALT more than 1.5 times) and fatty liver or hepatomegaly.

\section{Evaluating the relationship between CF phenotype and CFTR genotype}

Knowing the relationship between genotype and phenotype in cystic fibrosis, knowledge of modified genes, and different environmental influences help to gain a greater understanding of the manifestations of infection that may range from mild to severe, which may occur in one or several systems of the body [16].

One hundred eighty-three mutant alleles were detected from 196 examined alleles. The most prevalent pathogenic variant in the sample is F508del (36\%) followed by $W 1282 X(17 \%)$. This result was similar to the study of Jarjour and colleagues (18\% and $12 \%$ retrospectively).

We detected four pathogenic variants among Syrian patients which were not identified in previous studies $(2789+5 G>A, 2184 d e l A, 3849+10 K b C>T, 394 d e l T T)$.

The class I pathogenic variants that cause complete loss of CFTR protein occupied $31 \%$ of the total pathogenic variants. The frequency of $W 1282 X$ was $17 \%$. It was observed in many Middle Eastern countries such as Lebanon, Egypt, Algeria, and Tunisia [17]. It was also found more frequently than F508del in the eastern regions of Russia (of Jewish descent) [18]. Most cases were diagnosed in a relatively early age compared to the rest of the pathogenic variants. This may be due to their severe manifestations since the first month of life. The heterozygous for W1282X with F508del, R334W, and $R 1126 X$ was also found. The heterozygous for W1282X with $R 1126 X$ was associated with the severe manifestation of growth failure, gastrointestinal symptoms, and pancreatic insufficiency.

$2183 A A>G$ was recorded in $2 \%$ of the total pathogenic variants. It is a pathogenic frame shift variant (A to $G$ at 2183 and deletion of $\mathrm{A}$ at 2184). It was observed in Saudi Arabia, Egypt, Palestine, and Algeria. Patients who had this pathogenic variant suffered from classical manifestations of variable pulmonary disease and pancreatic insufficiency which could lead to moderate-severe symptoms [17]. In our study, the homozygous $2183 A A>G$ was associated with chronic diarrhea, meconium ileus, recurrent respiratory symptoms, bronchitis with Pseudomonas aeruginosa, failure to thrive, pancreatic insufficiency, and an early liver injury. The death occurred at the age of 1.5 years. The heterozygous for $2183 A A>G$ with $N 1303 K$ was associated with recurrent respiratory symptoms. The death occurred at the age of 7 months which did not allow any further symptoms to appear.
394delTT - a pathogenic frame shift variant-was not observed in Arabic and European reviewed studies, except in Finland, which was associated with the classical CF image [19]. In this study, 394delTT was observed in homozygous form. It was associated with gastrointestinal and respiratory symptoms, bronchitis with Pseudomonas aeruginosa, failure to thrive, pancreatic insufficiency, and liver disease, but the diagnosis was relatively late (7 years).

The frequency of the $R 347 \mathrm{P}$ was $6 \%$. This pathogenic variant occurs with a frequency of $0.2 \%$ in the world [20]. Although it belongs to mild class (IV), half of the cases in this study were associated with gastrointestinal symptoms, pulmonary symptoms, and growth failure. The infection was diagnosed at an early age (2 months), and the quarter of cases was associated with liver disease and pancreatic insufficiency. These results were similar to a German study, Varon et al., which indicated that patients who had R347P on CFTR gene suffered from early pulmonary and gastrointestinal symptoms [20]. However, $R 334 \mathrm{~W}$ from the same class was associated with mild manifestations.

It was observed that patients with one pathogenic variant had an increased risk of developing respiratory infections and pancreatitis in the late stages of the life. However, most of carriers in this study had severe manifestations at an early age, which may suggest the presence of other pathogenic variant that was not detected by the mentioned kits and that leads to the necessity for doing CFTR gene sequencing to patients.

According to a Mckone and colleagues' study, patients who had classes IV and V pathogenic variants were observed to have mild symptoms with lower mortality rates compared to patients who had classes I and II pathogenic variants [21].

We studied the relationship between phenotype and genotype as shown in Table 4. This study showed a statistical difference when studying the frequency of steatorrhea between the group of patients who had two class I pathogenic variants and the ones who had two-class (IV, V) pathogenic variants $(68.4 \%, 1.11 \%$, respectively; value $\mathrm{P}<0.013)$. There was another statistical difference between the group of patients who had two class I pathogenic variants and the ones who had two pathogenic variants [a class I/II pathogenic variant with a class IV/V pathogenic variant] $[68.4 \%, 0 \%$, respectively; $\mathrm{p}$ value $<$ $0.011]$.

The presence of a relationship between the frequency of pancreatic insufficiency and the class I pathogenic variants that cause protein loss is normal. However, it is unusual that the relationship did not appear in the presence of severe F508del pathogenic variant (24 cases were associated with pancreatic sufficiency). This may be due to the fact that the severity of pancreatic insufficiency 
usually increases in older ages. This result was consistent with Cipolli and colleagues' study [22].

No significant statistical differences were observed between the pathogenic variant classes when studying other clinical features. However, the frequency of growth failure and recurrent respiratory and pulmonary disease in patients who had two-class (I/II/III) pathogenic variants was slightly higher compared to the group of patients who had at least one of the class (IV/V) pathogenic variants. This may be due to the small size of the sample in addition to the role of various environmental factors like low living conditions, especially during the war, which may play a role in the emergence of symptoms in all patients regardless of the classes of pathogenic variants.

The incidence of meconium ileus may be affected by certain CFTR pathogenic variant classes [23]. Pathogenic variants may have a high (G542X), medium (F508del), or low (G85E) incidence rate [24]. A higher frequency of meconium ileus was observed in patients who had classes I, II, and III pathogenic variants (29.6\%) compared to those who had at least one class (IV, V) pathogenic variant (14.3\%).

A statistical difference was observed when studying the mortality rate between the group of patients who had two class II pathogenic deletion variants and those who had two-class (IV, V) pathogenic variants $(38.9 \%$, $0 \%$, respectively; P value $<0.04$ ). The mortality rate in patients who had two-class (I/II/III) pathogenic variants was higher compared to its rate in patients who had at least one-class (IV/V) pathogenic variant $[35.2 \%, 7.1 \%$, respectively].

A high-risk genotype is associated with a higher mortality rate, this finding was similar to the 2006 Mckone and colleagues' study [25]. This may be partially due to increasing cases of malnutrition, meconium ileus, pulmonary disease, and pancreatic insufficiency in these groups. More studies are needed on larger samples and older ages.

\section{Conclusions}

The number of cases diagnosed with cystic fibrosis in Syria is less than the number of real cases, and there is a need to perform CFTR gene sequencing to determine the spectrum of the most common pathogenic variants in Syria. Although most of the studied cases were diagnosed in early life, this was due to the classical manifestation that appeared on patients at an early age, not as a result of good awareness. An initial relationship was observed between the genotype and both of pancreatic symptoms and the incidence of death. However, this is a retrospective study that relied on clinical observations from medical records, and not all the tests that are required for evaluation were conducted on all patients. Future studies will be needed to study the relationship between the genotype and the phenotype by using more reliable evidences [e.g., elastase and lung function tests (FEV1)] to assess the relationship more accurately and monitor disease progression.

\section{Abbreviations \\ CF: Cystic fibrosis; CFTR: Cystic fibrosis transmembrane conductance regulator; AST: Aspartate aminotransferase; ALT: Alanine aminotransferase; FEV1: Forced expiratory volume in $1 \mathrm{~s}$}

\section{Acknowledgements}

Not applicable.

\section{Declarations}

\section{Authors' contributions}

RB: conceived and designed the experiments, performed the experiments, analyzed and interpreted the data, contributed analysis tools or data, wrote the paper.

ABZ: conceived and designed the experiments, analyzed and interpreted the data.

The authors have read and approved the manuscript.

\section{Funding}

Not applicable.

\section{Availability of data and materials}

The authors can confirm that all relevant data are included in the manuscript.

\section{Ethics approval and consent to participate}

This is a retrospective study. Therefore, according to our local ethics committee, ethics approval is unnecessary. This study contains no data disclosing patient identity.

Consent for publication

Not applicable.

\section{Competing interests}

The authors declare that they have no competing interests.

Received: 27 February 2021 Accepted: 20 May 2021

Published online: 21 June 2021

References

1. Horsley A, Cunningham S, Innes AJ (2010) Genetics and pathophysiology. In: Horsley A, Cunningham S, Innes AJ (eds) Cystic Fibrosis. Oxford University Press, pp 1-17

2. Marshall SG, Borowitz D (2016) Molecular genetics of cystic fibrosis trans membrane conductance regulator: genotype and phenotype. In: Marshall SG, Borowitz D (eds) Cyst. Fibros "cystic fibrosis, an issue of pediatric clinics of north America". Elsevier, pp 585-598

3. De Gracia J, Mata F, Alvarez A, Casals T, Gatner S, Vendrell M, De la Rosa D, Guarner L, Hermosilla E (2005) Genotype-phenotype correlation for pulmonary function in cystic fibrosis. Thorax. 60(7):558-563. https://doi.org/1 $0.1136 /$ thx.2004.031153

4. Bush A; Genotype phenotype correlations cystic fibrosis in "Cystic Fibrosis In The 21st Century"; Ed. Bush A; Pub. Karger; 2006: 61-68.

5. Jarjour RA, Al-Berrawi S, Ammar S, Majdalawi R (2015) Spectrum of cystic fibrosis mutations in Syrian patients. Minerva Pediatr 70(2):159-164. https:// doi.org/10.23736/S0026-4946.17.04280-3

6. Wahab AA, Janahi IA, Hebi S, Al-Hamed M, Kambouris M (2002) Cystic fibrosis in a child from Syria. Ann Trop Paediatr 22(1):53-55. https://doi.org/1 $0.1179 / 027249302125000157$

7. El-Falaki MM, Shahin WA, El-Basha NR, Ali AA, Mehaney DA, El-Attar MM (2014) Profile of cystic fibrosis in a single referral center in Egypt. J Adv Res 5(5):563-568. https://doi.org/10.1016/j.jare.2013.07.005 
8. Fitzsimmons S (2017) Cystic fibrosis foundation patient registry annual data report

9. Al-Mahroos F (1998) Cystic fibrosis in Bahrain incidence, phenotype, and outcome. J Trop Pediatr 44(1):35-39. https://doi.org/10.1093/tropej/44.1.35

10. Boussetta K, Khalsi F, Bahri Y, Belhadj I, Tinsa F, Messaoud TB, Hamouda S (2018) Cystic fibrosis in Tunisian children: a review of 32 children. Afr Health Sci 18(3):664-670. https://doi.org/10.4314/ahs.v18i3.24

11. Rafeey M, Jabarpoor-Bonyadi M, Vahedi A, Vahedi L (2017) Genetic pattern of cystic fibrosis patients in Azeri Turkish population. RusOMJ 6(1):101

12. Rawashdeh MD, Manal H (2000) Cystic fibrosis in Arabs: a prototype from Jordan. Ann Trop Paediatr 20(4):283-286. https://doi.org/10.1080/02724936.2 000.11748148

13. Liacouras CA, Piccoli DA (2008) Cystic fibrosis. In: Liacouras CA, Piccoli DA (eds) Pediatric Gastroenterology. MOSBY, pp 314-321

14. Mulley AG, Goroll AH (2009) Management of pancreatitis. In: Mulley AG, Goroll AH (eds) Primary care medicine: office evaluation and management of the adult patient 6th Ed. Lippincott Williams \& Wilkins, pp 578-581

15. Dankert-Roelse JE, Vernooij-Van LA (2011) Newborn screening for cystic fibrosis: pros and cons. Breathe. 8(1):24-30

16. Rosa KM, Lima ED, Machado CC, Rispoli T, Silveira VD, Ongaratto R, Comaru T, Pinto LA (2018) Genetic and phenotypic traits of children and adolescents with cystic fibrosis in Southern Brazil. J Bras Pneumol 44(6):498-504. https:// doi.org/10.1590/s1806-37562017000000418

17. Shahin WA, Mehaney DA, El-Falaki MM (2016) Mutation spectrum of Egyptian children with cystic fibrosis. Springerplus. 5(1):686. https://doi.org/1 0.1186/s40064-016-2338-7

18. Petrova NV, Kashirskaya NY, Vasilyeva TA, Timkovskaya EE, Voronkova AY, Shabalova LA, Kondratyeva El, Sherman VD, Novoselova OG, Kapranov NI, Zinchenko RA (2016) High prevalence of W1282X mutation in cystic fibrosis patients from Karachay-Cherkessia. J Cyst Fibros 15(3):e28-e32. https://doi. org/10.1016/j.jcf.2016.02.003

19. Kinnunen S, Bonache S, Casals T, Monto S, Savilahti E, Kere J, Järvelä I (2005) Spectrum of mutation in CFTR in Finland: 18 years follow-up study and identification of two novel mutations. J Cyst Fibros 4(4):233-237. https://doi. org/10.1016/j.jcf.2005.06.002

20. Varon R, Stuhrmann M, Macek M Jr, Kufardjieva A, Angelicheva D, Magdorf K, Jordanova A, Savov A, Wahn U, Macek M, Lalov V (1995) Pancreatic insufficiency and pulmonary disease in German and Slavic cystic fibrosis patients with the R347P mutation. Hum Mutat 6(3):219-225. https://doi. org/10.1002/humu.1380060304

21. Mckone EF, Emerson SS, Edwards KL, Aitken ML (2003) Effect of genotype on phenotype and mortality in cystic fibrosis: a retrospective cohort study. Lancet. 361(9370):1671-1676. https://doi.org/10.1016/S0140-6736(03)13368-5

22. Cipolli M, Castellani C, Wilcken B, Massie J, Mckay K, Gruca M, Tamanini A, Assael MB, Gaskin K (2007) Pancreatic phenotype in infants with cystic fibrosis identified by mutation screening. Arch Dis Child 92(10):842-846. https://doi.org/10.1136/adc.2006.107581

23. Bouhamdan M, Youming X, Sun F (2018) Structure-function relationships of CFTR in health and disease: the pancreas story. Pancreapedia

24. Dupuis A, Keenan K, Ooi CY, Dorfman R, Sontag MK, Naehrlich L, Castellani C, Strug L, Rommens JM, Gonska T (2016) Prevalence of meconium ileus marks the severity of mutations of the cystic fibrosis trans membrane conductance regulator (CFTR) gene. Genet Med 18(4):333-340. https://doi. org/10.1038/gim.2015.79

25. Mckone EF, Goss CH, Aitken ML (2006) CFTR genotype as a predictor of prognosis in cystic fibrosis. Chest. 130(5):1441-1447. https://doi.org/10.1378/ chest.130.5.1441

\section{Publisher's Note}

Springer Nature remains neutral with regard to jurisdictional claims in published maps and institutional affiliations.

\section{Submit your manuscript to a SpringerOpen ${ }^{\circ}$ journal and benefit from:}

- Convenient online submission

- Rigorous peer review

- Open access: articles freely available online

High visibility within the field

- Retaining the copyright to your article

Submit your next manuscript at $\boldsymbol{\nabla}$ springeropen.com 